\title{
PENYEBAB DEPRESI PADA USIA LANJUT DI PANTI SOSIAL TRESNA WERDHA MINAULA
}

\author{
Causes of Depression in Elderly in Social Institution Tresna \\ Werdha Minaula
}

\author{
Taamu, Nurjannah, Abd Syukur Bau, La Banudi \\ Poltekkes Kemenkes Kendari \\ (labanudibanudi@yahoo.com)
}

\begin{abstract}
ABSTRAK
Peningkatan jumlah penduduk usia lanjut menyebabkan perlunya perhatian dengan harapan usia lanjut tidak hanya berumur panjang, tetapi juga dapat menikmati masa tuanya dengan bahagia. Salah satu gangguan kesehatan yang dapat muncul pada usia lanjut adalah depresi. Tujuan penelitian adalah mengetahui faktor yang berhubungan dengan depresi pada usia lanjut di Panti Sosial Tresna Werdha Minaula Kendari Tahun 2015. Jenis penelitian ini adalah penelitian analitik dengan pendekatan cross sectional. Populasi adalah seluruh usia lanjut di Panti Sosial Tresna Werdha Minaula Kendari sebanyak 90 orang dengan besar sampel sebanyak 41 orang, pemilihan sampel secara purposive sampling. Uji chi square menunjukkan bahwa ada hubungan yang bermakna antara stressor lingkungan $(\mathrm{p}=0,045)$, tipe kepribadian $(\mathrm{p}=0,019)$, dan dukungan keluarga $(\mathrm{p}=0,047)$ dengan depresi usia lanjut. Hasil analisis Multivariat bahwa variabel independen yang paling dominan berhubungan dengan depresi pada usia lanjut yaitu variabel tipe kepribadian dengan nilai kemaknaan $\operatorname{Exp}(B)=2,726$. Kesimpulan penelitian adalah adanya hubungan antara stressor lingkungan, tipe kepribadian dan dukungan keluarga dengan depresi pada usia lanjut. Saran untuk Panti Sosial Tresna Werdha agar mengadakan pelatihan ringan misalnya memberikan pelatihan penilaian kepribadian, peningkatan mekanisme koping pada usia lanjut, dan menyediakan layanan konseling invidu dan konseling kelompok bagi sesama usia lanjut.
\end{abstract}

Kata kunci : Depresi, stressor lingkungan, tipe kepribadian

\section{ABSTRACT}

Increasing the number of elderly people led to the need for elderly care in the hope not only live longer but also enjoy their old age happily, one of the health problems that may arise in the elderly is depression. The research objective was to determine the factors associated with depression in the elderly in Social Institutions Tresna Werdha Minaula Kendari Year 2015. This type of research is analytic research with cross sectional approach. The population of elderly in Social Institutions Tresna Werdha Minaula Kendari many as 90 people with a sample size of 41 people, sample selection by purposive sampling. Chi-square test showed that there is a significant relationship between environmental stressors $(p=0,045)$, personality type $(p=0,019)$, and family support $(p=0,047)$ with the depressed elderly. Multivariate analysis results that the most dominant independent variable associated with depression in the elderly is the variable type of personality with a significance value of $\operatorname{Exp}(B)=2,726$. Conclusion of the study is the relationship between environmental stressors, the type of personality and family support with depression in the elderly. Suggestions for Social Institutions that conduct training Tresna Werdha mild personality assessments such as providing training, improved coping mechanisms in the elderly, and providing counseling services invidu and peer group counseling for the elderly.

Keywords : Depression, environmental stressors, personality type 


\section{PENDAHULUAN}

Peningkatan jumlah penduduk usia lanjut menyebabkan perlunya perhatian pada usia lanjut dengan harapan usia lanjut tidak hanya berumur panjang, tetapi juga dapat menikmati masa tuanya dengan bahagia serta meningkatkan kualitas hidup diri lansia. Menurut hirarki kebutuhan dasar manusia Maslow, terdapat lima kebutuhan dasar manusia yang harus terpenuhi yaitu kebutuhan fisiologis, keamanan dan kenyamanan, mencintai dan dicintai, harga diri dan aktualisasi diri. ${ }^{1}$

Salah satu gangguan kesehatan yang dapat muncul pada usia lanjut adalah gangguan mental. Depresi merupakan gangguan yang banyak dialami oleh orang tua meskipun depresi banyak terjadi dikalangan usia lanjut, depresi ini sering salah didiagnosis atau diabaikan. Sejumlah faktor yang menyebabkan keadaan ini, mencakup fakta bahwa pada usia lanjut, depresi dapat disamarkan atau tersamarkan oleh gangguan fisik lainnya. Depresi merupakan gangguan mental yang terjadi di tengah masyarakat, berawal dari stres yang tidak diatasi, maka seseorang bisa jatuh ke fase depresi. Penyakit ini sering diabaikan karena dianggap bisa hilang tanpa pengobatan. ${ }^{2,3}$

Menurut data Badan Kesehatan Dunia (WHO), saat ini sekitar $5-10 \%$ orang di dunia mengalami depresi yang merupakan masalah mental yang paling banyak ditemui pada usia lanjut. Prevalensi depresi pada usia lanjut di dunia sekitar $8-15 \%$, hasil survei dari berbagai negara di dunia diperoleh prevalensi rata-rata depresi pada usia lanjut adalah 13,5\% dengan perbandingan wanita dan pria $14,1: 8,5$. Sementara prevalensi depresi pada usia lanjut yang menjalani perawatan di RS dan Panti Perawatan sebesar $30-45 \%{ }^{4}$

Depresi merupakan kondisi emosi yang biasanya ditandai dengan kesedihan yang sangat mendalam, perasaan tidak berarti dan bersalah, menarik diri dari orang lain, tidak dapat tidur, kehilangan selera makan, hasrat seksual, dan minat serta kesenangan dalam aktivitas yang biasa dilakukan. Faktor penyebab depresi pada lansia antara lain adalah faktor biologi, faktor genetik, dan faktor psikososial. Adapun faktor psikososial penyebab depresi pada usia lanjut dalam penelitian ini antara lain adalah stressor lingkungan, tipe kepribadian, dan dukungan keluarga. ${ }^{5,6}$

Panti Sosial Tresna Werdha Minaula Ken- dari merupakan salah satu tempat untuk merawat usia lanjut di kota Kendari. Berdasarkan studi pendahuluan pada tanggal 6 Desember 2014 di Panti Sosial Tresna Werdha Minaula Kendari terdapat 90 orang lansia, staf pegawai panti menjelaskan jumlah lansia terdiri dari laki-laki 44 orang dan perempuan 46 orang yang tinggal di panti sosial tersebut. Penelitian ini bertujuan mengetahui faktor yang berhubungan dengan depresi pada usia lanjut di Panti Sosial Tresna Werdha Minaula Kendari.

\section{BAHAN DAN METODE}

Rancangan penelitian ini menggunakan penelitian deskriptif analitik, menjelaskan kondisi variabel penelitian yang ada di Panti Tresna Werda Kendari. Penelitian ini dilaksanakan pada bulan Agustus - Oktober 2015 di Panti Sosial Tresna Werdha Minaula Kendari. Populasi adalah keseluruhan objek penelitian atau objek yang diteliti. ${ }^{7}$ Populasi dalam penelitian ini adalah seluruh usia lanjut di Panti Sosial Tresna Werdha Minaula Kendari sebanyak 90 orang lansia. Penentuan besar sampel menggunakan cara purposive sampling dengan besar sampel sebanyak 41 responden. Data yang telah dikumpulkan dianalisis secara univariat, bivariat dan multivariat dengan menggunakan komputer.

\section{HASIL}

Tabel 1 diperoleh informasi bahwa mayoritas responden berjenis kelamin laki-laki, dengan sebaran responden berjenis kelamin laki-laki sebanyak 21 orang atau $(51,2 \%)$ dan responden yang berjenis kelamin perempuan sebanyak 20 orang atau $(48,8 \%)$. Mayoritas responden berada pada kelompok umur 60-74 tahun, yaitu sebanyak 27 orang $(65,9 \%)$, sebanyak 13 orang $(31,7 \%)$ kelompok umur 75-90 tahun, dan hanya 1 orang $(2,4 \%)$ responden berada pada kelompok umur diatas 90 tahun.

Tabel 1 juga menunjukkan bahwa sebagian besar tingkat pendidikan responden berada pada tingkat SR/SD, yaitu sebanyak 22 orang $(53,7 \%)$, dan hanya 2 orang $(4,9 \%)$ yang memiliki tingkat pendidikan SMA. Terdapat 12 orang $(29,3 \%)$ yang tidak pernah bersekolah, sisanya sebanyak 5 orang $(12,2 \%)$ memiliki pendidikan setingkat SMP. Selanjutnya dari 41 responden yang diteliti, seba- 
Tabel 1. Karakteristik Responden

\begin{tabular}{|c|c|c|}
\hline Karakteristik & n (41) & $\%$ \\
\hline \multicolumn{3}{|l|}{ Jenis Kelamin } \\
\hline Laki-laki & 21 & 51,2 \\
\hline Perempuan & 20 & 48,8 \\
\hline \multicolumn{3}{|l|}{ Kelompok Umur (tahun) } \\
\hline $60-74$ & 27 & 65,9 \\
\hline $75-90$ & 13 & 31,7 \\
\hline$>90$ & 1 & 2,4 \\
\hline \multicolumn{3}{|l|}{ Tingkat Pendidikan } \\
\hline Tidak Sekolah/Tidak Tamat SD & 12 & 29,3 \\
\hline $\mathrm{SD} / \mathrm{SR}$ & 22 & 53,7 \\
\hline SMP & 5 & 12,2 \\
\hline SMA & 2 & 4,9 \\
\hline \multicolumn{3}{|l|}{ Depresi Usia Lanjut } \\
\hline Depresi & 22 & 53,7 \\
\hline Tidak depresi & 19 & 46,3 \\
\hline \multicolumn{3}{|l|}{ Stressor Lingkungan } \\
\hline Stres lingkungan & 22 & 53,7 \\
\hline Tidak stress lingkungan & 19 & 46,3 \\
\hline \multicolumn{3}{|l|}{ Tipe Kepribadian } \\
\hline Kepribadian Ekstrovert & 20 & 48,8 \\
\hline Kepribadian Introvert & 21 & 51,2 \\
\hline \multicolumn{3}{|l|}{ Dukungan Keluarga } \\
\hline Baik & 17 & 41,5 \\
\hline Kurang & 24 & 58,5 \\
\hline
\end{tabular}

Sumber : Data Primer, 2015

nyak 22 orang $(53,7 \%)$ telah mengalami depresi, sedangkan responden yang tidak mengalami depresi berjumlah 19 orang (46,3\%). Hal ini menunjukkan bahwa keadaan usia lanjut di Panti Sosial Tresna Werdha Minaula Kendari Tahun 2015 mayoritas mengalami depresi. Lansia yang mengalami stres akibat lingkungan berjumlah 22 orang $(53,7 \%)$, sedangkan usia lanjut yang tidak mengalami stres akibat lingkungan berjumlah 19 orang $(46,3 \%)$ (Tabel 1).

Dari 41 responden yang diteliti, terdapat 20 orang $(48,8 \%)$ dengan tipe kepribadian ekstrovert, sedangkan responden dengan tipe kepribadian introvert berjumlah 21 orang $(51,2 \%)$. Hal ini berarti bahwa mayoritas usia lanjut di Panti Sosial Tresna Werdha Minaula Kendari Tahun 2015 memiliki tipe kepribadian introvert. Usia lanjut yang mendapat dukungan keluarga dengan kategori baik berjumlah 17 orang $(41,5 \%)$, sedangkan usia lanjut yang kurang mendapat dukungan keluraga sebanyak 24 orang $(58,5)$ (Tabel 1).

Distribusi pada Tabel 2 menunjukkan ada- nya hubungan antara stressor lingkungan dengan depresi pada usia lanjut, gambaran tersebut diperoleh melalui sebaran kondisi responden yakni dari 22 orang yang mengalami stres lingkungan, terdapat 15 orang $(36,6 \%)$ yang mengalami depresi, dan hanya 7 orang $(17,1 \%)$ yang tidak mengalami depresi. Selanjutnya dari 19 orang yang tidak mengalami stres lingkungan, terdapat 12 orang $(29,3 \%)$ yang tidak mengalami depresi, dan hanya 7 orang $(17,1 \%)$ yang mengalami depresi. Hasil uji statistik dengan uji chi square diperoleh nilai $\mathrm{p}=0,045$. Disimpulkan bahwa ada hubungan yang signifikan antara stressor lingkungan dengan depresi pada usia lanjut di Panti Sosial Tresna Werdha Minaula Kendari tahun 2015.

Selanjutnya hubungan antara tipe kepribadian dengan depresi pada usia lanjut. Gambaran tersebut diperoleh melalui sebaran kondisi responden yakni dari 20 orang usia lanjut dengan kepribadian ekstrovert terdapat 13 orang $(31,7 \%)$ yang tidak mengalami depresi dan hanya 7 orang $(17,1 \%)$ yang mengalami depresi. Selanjutnya dari 21 orang usia lanjut yang memiliki kepribadian introvert terdapat 15 orang $(36,6 \%)$ mengalami depresi, dan hanya 6 orang $(16,1 \%)$ tidak mengalami depresi. Berdasarkan hasil uji statistik dengan uji chi square menggunakan SPSS pada tingkat kepercayaan $95 \%(\alpha=0,05)$ diperoleh nilai $\mathrm{p}=0,019$. Hal ini berarti ada hubungan yang signifikan antara tipe kepribadian dengan depresi pada usia lanjut di Panti Sosial Tresna Werdha Minaula Kendari (Tabel 2).

Hasil penelitian menunjukkan bahwa dari 17 orang usia lanjut yang memiliki dukungan keluarga yang baik, terdapat 11 orang $(26,8 \%)$ yang tidak mengalami depresi dan hanya 6 orang $(14,6 \%)$ yang mengalami depresi. Selanjutnya dari 23 orang yang kurang memiliki dukungan keluarga, terdapat 16 orang $(39,0 \%)$ yang mengalami depresi dan hanya 8 orang $(19,5 \%)$ yang tidak mengalami depresi. Uji statistik dengan nilai $\mathrm{p}=0,047$, menunjukan bahwa ada hubungan yang signifikan antara dukungan keluarga dengan depresi pada usia lanjut di Panti Sosial Tresna Werdha Minaula Kendari tahun 2015 (Tabel 2).

Tabel 3 menguraikan bahwa variabel yang paling berhubungan dengan depresi pada usia lanjut di Panti Sosial Tresna Werdha Minaula Kendari, yaitu tipe kepribadian. Hal ini berdasarkan 
Tabel 2. Faktor Penyebab Depresi Pada Usia Lanjut

\begin{tabular}{|c|c|c|c|c|c|c|c|}
\hline \multirow{3}{*}{ Variabel } & \multicolumn{4}{|c|}{ Depresi pada Usia Lanjut } & \multirow{2}{*}{\multicolumn{2}{|c|}{ Jumlah }} & \multirow{3}{*}{$\mathbf{p}$} \\
\hline & \multicolumn{2}{|c|}{ Depresi } & \multicolumn{2}{|c|}{ Tidak Depresi } & & & \\
\hline & $\mathbf{n}$ & $\%$ & $\mathbf{n}$ & $\%$ & $\mathbf{n}$ & $\%$ & \\
\hline \multicolumn{8}{|l|}{ Stressor Lingkungan } \\
\hline Stres lingkungan & 15 & 36,6 & 7 & 17,1 & 22 & 53,7 & 0,045 \\
\hline Tidak & 7 & 17,1 & 12 & 29,3 & 19 & 46,3 & \\
\hline \multicolumn{8}{|l|}{ Tipe Kepribadian } \\
\hline Ekstrovert & 7 & 17,1 & 13 & 31,7 & 20 & 48,8 & 0,019 \\
\hline Introvert & 15 & 36,6 & 6 & 14,6 & 21 & 51,2 & \\
\hline \multicolumn{8}{|l|}{ Dukungan Keluarga } \\
\hline Baik & 6 & 14,6 & 11 & 26,8 & 17 & 41,5 & 0,047 \\
\hline Kurang & 16 & 39,0 & 8 & 19,5 & 24 & 58,5 & \\
\hline
\end{tabular}

Sumber : Data Primer, 2015

nilai $\operatorname{Exp}(B)=2,726$ dengan asumsi bahwa semakin besar nilai Exp (B) berarti semakin besar hubungannya terhadap variabel dependen yang dianalisis.

\section{PEMBAHASAN}

Hasil analisis univariat dari 41 responden sebanyak 22 usia lanjut (53,7\%) mengalami depresi. Menurut teori bahwa usia lanjut adalah suatu keadaan yang ditandai oleh kegagalan dari makhluk hidup untuk mempertahankan keseimbangan (homeostatis) terhadap kondisi stres fisiologis. ${ }^{8}$ Teori lain menyatakan bahwa depresi pada usia lanjut dikarenakan secara alamiah usia lanjut itu mengalami penurunan baik dari segi biologi maupun mentalnya dan hal ini tidak terlepas dari masalah ekonomi, sosial dan budaya. ${ }^{9}$ Secara sederhana dapat dikatakan bahwa depresi adalah suatu pengalaman yang menyakitkan, suatu perasaan tidak ada harapan lagi. Depresi adalah suatu perasaan sendu atau sedih yang biasanya disertai dengan diperlambatnya gerak dan fungsi tubuh. Mulai dari perasaan murung sedikit sampai pada keadaan tak berdaya. ${ }^{10}$

Dari 41 responden sekitar 22 responden
$(53,7 \%)$ mengalami stres lingkungan. Tekanan yang didapatkan seseorang dari lingkungannya bisa menyebabkan seseorang tidak mendapatkan harapannya sehingga mengalami ketegangan dan tekanan dari lingkungan yang perubahannya serba cepat. Terkadang lingkungan sering menimbulkan masalah dan kejengkelan karena keadaannya sangat buruk berbeda dengan pola hidup seseorang yang didambakannya. ${ }^{11}$ Gangguan ini menyebabkan terjadinya perilaku manipulatif pada individu yakni perilaku agresif, melawan/menentang terhadap orang yang menghalangi keinginannya atau dalam usaha untuk memenuhi kebutuhannya. Jika perilaku manipulatif tidak dapat mengatasi dalam menyelesaikan masalah, maka akan terjadi perilaku menarik diri sebagai usaha untuk menghindari interaksi dengan orang lain dan kemudian menghindari berhubungan terhadap masyarakat luas yang ada di sekitarnya. ${ }^{8,12}$

Seseorang mengalami depresi karena kurang mendapatkan dukungan positif dari lingkungan terhadap perilaku-perilakunya. Penjelasan lebih lanjut mengatakan bahwa dengan terapi perilaku, perilaku seseorang dapat dibentuk dengan memberikan penguatan positif dari Skinner yaitu

Tabel 3. Hasil Analisis Multivariat Faktor yang Berhubungan dengan Depresi pada Usia Lanjut

\begin{tabular}{lcccccccc}
\hline \multicolumn{1}{c}{ Variabel } & B & SE & Wald & Df & Sig & $\begin{array}{r}\text { Exp } \\
\text { (B) }\end{array}$ & \multicolumn{2}{c}{ 95\%CI Exp (B) } \\
\hline Stress lingkungan & 0,266 & 1,006 & 0,070 & 1 & 0,792 & 1,305 & 0,181 & Lower \\
Tipe Kepribadian & 1,003 & 1,037 & 0,935 & 1 & 0,334 & 2,726 & 0,357 & 20.805 \\
Dukungan keluarga & 0,642 & 0,801 & 0,642 & 1 & 0,423 & 1,900 & 0,395 & 9,133 \\
Constan & $-2,957$ & 1,248 & 5,616 & 1 & 0,018 & 0,052 & & \\
\hline
\end{tabular}

Sumber : Data Primer, 2015 
manusia selalu berusaha untuk melakukan tindakan. Jika tindakan yang dilakukannya mendapatkan penghargaan atau dukungan yang positif dari orang lain atau lingkungannya maka perilaku tersebut akan secara terus-menerus. Begitupun sebaliknya, jika lingkungan tidak mendukung perilaku yang diharapkan seseorang maka seseorang akan menimbulkan perilaku yang negatif seperti putus asa, tidak bahagia, merasa sendiri disebabkan lingkungan tidak mampu memahami perasaan dirinya. ${ }^{13}$

Sebanyak 21 responden $(51,2 \%)$ memiliki tipe kepribadian introvert atau mudah mengalami depresi dan sebanyak 20 responden $(48,8)$ memiliki tipe kepribadian ekstrovert. Masing-masing sifat dan kepribadian mempunyai konsekuensi pada interaksi dan hubungan orang tersebut. Orang-orang yang introvert memperlihatkan kecenderungan untuk mengembangkan gejala-gejala ketakutan dan depresi, ditandai oleh kecenderungan obsesi mudah tersinggung, apatis, syaraf otonom yang labil. ${ }^{8}$ Mereka juga gampang mengalami kesedihan dan putus asa. Orang yang memiliki tipe introvert juga memiliki perasaan rendah diri serta gampang cemburu, iri hati dan menghadapi dunia luar dengan penuh curiga, sedangkan seseorang bertipe kepribadian ekstrovert lebih menyenangi bersama dengan orang lain, mudah bergaul dan menyenangi bertemu dengan orang-orang yang baru, tidak merasa canggung dalam pergaulan. ${ }^{10}$

Hasil penelitian menunjukkan, sebanyak 24 responden $(58,5 \%)$ yang kurang mendapat dukungan dari keluarga. Dukungan keluarga mempengaruhi kemampuan usia lanjut untuk mencegah terjadinya stres dan depresi dalam kehidupannya dan meningkatkan kemampuan fungsional diantaranya kemampuan kognitif. ${ }^{11}$ Dukungan keluarga adalah suatu bentuk perilaku melayani yang dilakukan oleh keluarga baik dalam bentuk dukungan emosional, dukungan penghargaan, dukungan informasi dan dukungan instrumental. Dukungan keluarga mengacu kepada dukungan yang dipandang oleh anggota keluarga sebagai suatu yang dapat diakses atau diadakan oleh keluarga, dukungan bisa atau tidak digunakan, tetapi anggota keluarga memandang bahwa orang yang bersifat mendukung selalu siap memberikan pertolongan dan bantuan jika diperlukan. ${ }^{14,15}$

Stres didefinisikan sebagai proses de- ngan kejadian lingkungan yang mengancam atau hilangnya kesejahteraan organisme yang menimbulkan beberapa respon dari organisme tersebut. Respon ini bisa dalam bentuk coping behavior (tingkah laku penyesuaian) terhadap ancaman. Kejadian-kejadian lingkungan yang menyebabkan proses ini disebut sebagai sumber stres (stressor) yang antara lain berupa bencana alam dan teknologi, bising dan commuting, sedangkan reaksi yang timbul karena adanya stressor disebut respons dari stress (stress response). Hasil penelitian menunjukkan bahwa ada hubungan yang signifikan antara stressor lingkungan dengan depresi usia lanjut di Panti Sosial Tresna Werdha Minaula Kendari tahun 2015.

Kaitan stres dan depresi adalah individu yang tidak berdaya dalam mengendalikan situasi-situasi menekan, akibat kegagalannya mengatasi masalah berulang-ulang, kecemasannya merupakan respon awal terhadap situasi yang penuh stres, sehingga apabila individu tiba pada anggapan bahwa situasi tersebut sudah tidak terkendali, rasa cemas akan berkembang menjadi sebuah depresi. ${ }^{16}$ Pendapat lain menyatakan bahwa manusia selalu ingin dan berusaha mencapai keseimbangan dalam hidupnya. Jika mendapatkan kesulitan, maka akan berusaha mencari kesenangan lain, akan tetapi terkadang tidak sesuai dengan tujuannya untuk mencapai keseimbangannya, sehingga menimbulkan rasa kesal dan tekanan batin. Tekanan batin yang tidak diintervensi secara tepat akan mengakibatkan depresi. Karakteristik pasien yang mengalami gangguan depresi dalam berhubungan dengan orang lain dapat berupa ketidaknyamanan dalam menjalankan interaksi sosial, ketidakmampuan untuk menerima pendapat orang lain, mengalami gangguan interaksi dengan teman-teman dekat, keluarga, dan orang-orang terdekat lainnya. ${ }^{17}$

Telah diketahui bahwa dari 41 orang responden ada 22 orang yang mengalami stressor lingkungan dan ada 19 orang yang tidak mengalami stressor lingkungan. Hal ini disebabkan karena seseorang dalam kehidupannya berinteraksi dengan lingkungan dan tergantung pada lingkungan. Lingkungan dengan kesehatan mental sangat berpengaruh karena dengan lingkungan yang terganggu akan menyebabkan mental akan terganggu juga, seperti adanya perisitwa negatif 
yang menyebabkan perubahan, pengalaman penuh stres yang ekstrem seperti bencana alam, perang, kematian, pertengkaran, perceraian, serta mikrostresor yang meliputi aktivitas sehari-hari. Hal ini sesuai dengan penelitian lain bahwa orang yang mengalami stres penuh tekanan dalam kehidupannya secara terus-menerus mempunyai kecenderungan mengalami depresi serta melaporkan hal-hal negatif dalam kehidupannya. ${ }^{14}$

Kepribadian yaitu keseluruhan pola pikiran, perasaan dan perilaku yang sering digunakan oleh seseorang dalam usaha adaptasi yang terus menerus terhadap hidupnya. Segala corak dan perilaku manusia yang terhimpun dalam dirinya dan yang digunakan untuk bereaksi serta menyesuaikan dirinya terhadap segala rangsangan, baik yang datang dari lingkungannya ("dunia luar"-nya) maupun yang berasal dari dirinya sendiri ("dunia dalam"-nya), sehingga corak perilakunya menjadi suatu kesatuan fungsional yang khas bagi manusia itu. ${ }^{18,19}$

Depresi sudah begitu populer dalam masyarakat dan semua orang mengetahuinya, termasuk orang yang awam, akan tetapi arti sebenarnya dari depresi itu sukar didefinisikan secara tepat. Lubis menjelaskan lebih lanjut bahwa depresi adalah kata yang memiliki banyak nuansa arti, manusia sering mengalami sedih, menjalani kehidupan yang penuh dengan masalah, merasa kecewa, kehilangan dan frustrasi yang denga mudah menimbulkan ketidakbahagiaan dan keputusasaan. ${ }^{14}$ Depresi adalah kemuraman hati (kepedihan, kesenduhan, keburaman perasaan) yang patologis sifatnya. Dari beberapa definisi menggambarkan bahwa semua ciri-ciri orang depresi terdapat tipe kepribadian introvert (tertutup), sikap tertutup inilah yang membuat para usia lanjut tidak mampu berinteraksi dengan masyrakat sosial karena merasa dirinya sedih dan murung. ${ }^{16}$

Telah diketahui bahwa dari 41 orang responden ada 20 orang yang bertipe kepribadian ekstrovert dan ada 21 orang yang bertipe kepribadian introvert. Usia lanjut lebih banyak yang bertipe kepribadian introvert, orang-orang yang introvert itu memperlihatkan kecenderungan untuk mengembangkan gejala-gejala ketakutan dan depresi, ditandai oleh kecendrungan obsesi mudah tersinggung, apatis, syaraf otonom yang labil. Menurut pernyataan mereka sendiri perasaan me- reka gampang terluka, mudah gugupan, menderita rasa rendah diri, mudah melamun, dan sukar tidur. Jung menguraikan perilaku introvert sebagai seorang pendiam, menjauhkan diri dari kejadian luar, tidak mau terlibat dalam dunia objektif, tidak senang berada ditengah orang banyak. Semakin banyak orang semakin besar pula daya tolaknya. Seseorang yang tipe pribadinya introvert cenderung merasa mampu dalam upaya mencukupi dirinya sendiri, sedangkan seseorang yang tipe pribadinya ekstrovert membutuhkan orang lain. ${ }^{5,20}$

Keluarga merupakan kelompok sosial utama yang mempunyai ikatan emosi yang paling besar terhadap seseorang. Bagi usia lanjut, keluarga merupakan sumber kepuasaan. Para usia lanjut merasa bahwa kehidupan mereka sudah lengkap, yaitu sebagai orang tua dan juga sebagai kakek dan nenek. Hasil penelitian menunjukkan bahwa ada hubungan yang bermakna antara dukungan keluarga dengan depresi usia lanjut di Panti Sosial Tresna Werdha Minaula Kendari tahun 2015.

Dukungan keluarga merupakan suatu upaya pencegahan terjadinya depresi pada usia lanjut. Dukungan keluarga merupakan suatu bentuk hubungan interpersonal yang melindungi seseorang dari efek stress yang buruk, dukungan keluarga juga dapat memberikan petunjuk tentang kesehatan mental, fisik, dan emosi lansia. Usia lanjut yang mendapatkan dukungan dari keluarga dan lingkungannya memperlihatkan kondisi kesehatan fisik dan mental yang baik daripada usia lanjut yang tidak mendapatkan dukungan dari keluarganya. Dukungan keluarga tersebut dapat dirasakan oleh usia lanjut berupa dukungan emosional, dukungan penghargaan, dukungan informasi dan dukungan instrumental. Ikatan kekeluargaan yang kuat sangat membantu ketika usia lanjut menghadapi masalah karena keluarga adalah orang yang paling dekat hubungannya dengan usia lanjut. ${ }^{5}$

Telah diketahui bahwa dari 41 orang responden ada 24 orang yang kurang mendapatkan dukungan keluarga dan 17 orang yang mendapatkan dukungan keluarga (kriteria baik). Dukungan keluarga merupakan suatu proses hubungan antara keluarga dengan lingkungan sosialnya. Seseorang sangat membutuhkan dukungan dari keluarganya karena hal ini membuat individu tersebut merasa dihargai dan anggota keluarga siap memberikan dukungan untuk menyediakan bantuan dan tujuan 
hidup yang ingin dicapai oleh seseorang. ${ }^{17}$

Hsil penelitian menunjukkan bahwa variabel yang dominan berpengaruh terhadap depresi pada usia lanjut, yaitu tipe kepribadian. Kepribadian yaitu keseluruhan pola pikiran, perasaan dan perilaku yang sering digunakan oleh seseorang dalam usaha adaptasi yang terus menerus terhadap hidupnya. ${ }^{1}$

Tekanan yang didapatkan seseorang dari lingkungannya bisa menyebabkan seseorang tidak mendapatkan harapannya sehingga mengalami ketegangan dan tekanan, dari lingkungan yang perubahannya serba cepat. Terkadang lingkungan sering menimbulkan masalah dan kejengkelan karena keadaannya sangat buruk berbeda dengan pola hidup seseorang yang didambakannya. Hal ini disebabkan seseorang dalam kehidupannya berinteraksi dengan lingkungan dan tergantung pada lingkungan, lingkungan dengan kesehatan mental sangat berpengaruh karena dengan lingkungan yang terganggu akan menyebabkan mental akan terganggu juga.

Kaitan stres dan depresi adalah bahwa individu yang tidak berdaya dalam mengendalikan situasi-situasi menekan, akibat kegagalannya mengatasi masalah berulang-ulang, kecemasannya merupakan respon awal terhadap situasi yang penuh stres, sehingga apabila individu tiba pada anggapan bahwa situasi tersebut sudah tidak terkendali, rasa cemas akan berkembang menjadi sebuah depresi. ${ }^{21}$ Seseorang yang memiliki kepribadian introvert memperlihatkan kecenderungan untuk mengembangkan gejala-gejala ketakutan dan depresi, ditandai oleh kecenderungan obsesi, mudah tersinggung, apatis, labil. Menurut pernyataan mereka sendiri mereka gampang terluka, mudah gugup, mengalami rendah diri, suka melamun, sukar tidur. Seseorang dengan kepribadian introvert merasa tidak mampu dan sangat membutuhkan orang lain. ${ }^{1,22}$

\section{KESIMPULAN DAN SARAN}

Ada hubungan yang signifikan dan positif antara stressor lingkungan, tipe kepribadian dan dukungan keluarga terhadap depresi pada usia lanjut di Panti Sosial Tresna Werdha Minaula Kendari Tahun 2015. Diantara ketiga kovariat yang berhubungan dengan depresi pada usia lanjut, faktor dominan yang berhubungan dengan depresi pada usia lanjut di Panti Sosial Tresna Werdha Minaula Kendari Tahun 2015 adalah tipe kepribadian. Diharapkan kepada pengurus Panti Sosial Tresna Werdha Minaula Kendari agar mengadakan pelatihan ringan, misalnya memberikan pelatihan kepribadian dalam memperlakukan para usia lanjut dan menyediakan layanan konseling individu dan konseling kelompok bagi sesama usia lanjut, agar tercipta suasana kekeluargaan. Diharapkan kepada para usia lanjut agar mengenali kepribadian sendiri dan mengembangkan kemampuan adaptasi atau mekanisme koping yang adaptif terhadap berbagai masalah yang dialami dalam kehidupan sehingga dapat meningkatkan kemampuan adaptasi dan dapat mencegah terjadinya depresi.

\section{DAFTAR PUSTAKA}

1. Azizah, Ma'rifatul L. Keperawatan lanjut usia. Yogyakarta: Graha Ilmu. 2011;45.

2. Stanley M, Beare PG. Buku ajar keperawatan gerontik. Edisi. 2007;2:375-99.

3. Staebler K, Renneberg B, Stopsack M, Fiedler P, Weiler M, Roepke S. Facial Emotional Expression in Reaction to Social Exclusion in Borderline Personality Disorder. Psychological medicine. 2011;41(9):1929-38.

4. Setyowati S, Murwani A. Asuhan Keperawatan Keluarga. Jakarta, Mitra Cendekia Press; 2008.

5. Chang E, Daly J, Elliott D. Patofisiologi: Aplikasi pada Praktik Keperawatan. Jakarta: EGC; 2010.

6. Hagger MS, Wood C, Stiff C, Chatzisarantis NL. Ego Depletion and the Strength Model of Self-control: a Meta-analysis. American Psychological Association; 2010.

7. Notoatmodjo S. Metodologi Penelitian Kesehatan. Jakarta: Rineka Cipta; 2005.

8. Gunarsa YSD, Gunarsa SD. Psikologi untuk Keluarga: Dewan Bahasa dan Pustaka, Kementerian Pelajaran, Malaysia; 1982.

9. Nugroho HW, editor Komunikasi dalam Keperawatan Gerontik. 2009: EGC.

10. Muslim R. Diagnosis Gangguan Jiwa Rujukan Ringkas dari PPDGJ III. Jakarta: Bagian Ilmu Kedokteran Jiwa FK Unika Atmajaya hlm. 2003:30-5.

11. Mubarak WI, Chayatin N. Ilmu Keperawatan Komunitas Pengantar dan Teori. Jakarta: Sa- 
lemba Medika. 2009.

12. Ensari I, Pilutti LA, Motl RW. Depressive Symptomology in Multiple Sclerosis: Disability, Cardiorespiratory Fitness and Heart Rate Variability. Acta Neurologica Scandinavica. 2017.

13. Aryani A. Faktor-Faktor yang Berhubungan dengan Depresi pada Lansia di Desa Mandong Kecamatan Trucuk Kabupaten Klaten: Universitas Muhammadiyah Surakarta; 2008.

14. Lubis NL. Depresi Tinjauan Psikologis. Jakarta: Prenada Media. 2009.

15. Hashimoto M, Araki Y, Takashima Y, Nogami K, Uchino A, Yuzuriha T, et al. Hippocampal Atrophy and Memory Dysfunction Associated with Physical Inactivity in Community-dwelling Elderly Subjects: The Sefuri study. Brain and behavior. 2017;7(2):e00620.

16. Idrus MF. Depresi pada Penyakit Parkinson. Jurnal Cermin Dunia Kedokteran. 2007;34(3/156).

17. Maryam RS, Ekasari MF, Rosidawati JA, Batubara I. Mengenal Usia Lanjut dan Perawatannya. Jakarta: Salemba Medika. 2008:9-
10.

18. Riyadi S, Purwanto T. Asuhan Keperawatan Jiwa. Yogyakarta: Graha Ilmu. 2009.

19. Sandström A, Peterson J, Sandström E, Lundberg M, NYSTROM ILR, Nyberg L, et al. Cognitive Deficits in Relation to Personality Type and Hypothalamic-Pituitary-Adrenal (HPA) Axis Dysfunction in Women with Stress-Related Exhaustion. Scandinavian Journal of Psychology. 2011;52(1):71-82.

20. Farida U. Hubungan Tipe Kepribadian Ekstrovert dan Introvert dengan Perilaku Agresif pada Remaja [Skripsi]. Malang: Universitas Islam Negeri Malang. 2007.

21. Purwitasari ND. Hubungan antara Tipe Kepribadian dengan Tingkat Depresi pada Lansia di Wilayah Desa Bumiharjo Kecamatan Nguntoronadi Kabupaten Wonogiri : Universitas Muhammadiyah Surakarta; 2008.

22. Lynch TR, Rosenthal MZ, Kosson DS, Cheavens JS, Lejuez C, Blair R. Heightened Sensitivity to Facial Expressions of Emotion in Borderline Personality Disorder. Emotion. 2006;6(4):647. 